\title{
Maintenance Management in an Un-renovated Building
}

\author{
Beata Nowogońska ${ }^{1 *}$, Magdalena Mielczarek ${ }^{2}$ \\ 1 Institute of Civil Engineering, University of Zielona Góra, Poland \\ 2 Institute of Civil Engineering, University of Zielona Góra, Poland \\ * Correspondence: b.nowogonska@ib.uz.zgora.pl Tel.: +48-68-3282-290 University of Zielona Góra, Institute \\ of Civil Engineering, Szafrana 1, 65-516 Zielona Góra, Poland
}

\begin{abstract}
The good management of the building maintenance should be based on the regular maintenance work. Repair works are often not carried out or there are shifts in time, which causes degradation of the building. The article presents a method of planning renovation works of a MUBAR (maintenance Management in an Un-renovated Building with Abandoning Renovation) based on the consequences in case of their lack. No renovation work on individual elements in a building can cause a threat to the stability of the building structure, risking the lives of users, continuing damage to the building by damaging further elements, or even a building disaster. The method can also be applied to historic buildings. Often, due to abandonment of repairs caused most often by lack of the owner, improper manager or irresponsible users, degradation of these objects occurs. The consequences of neglected renovation of buildings lead to irreversible processes of their destruction. The aim of the article is to present the developed method of planning renovation works based on the consequences of lack of renovation works.
\end{abstract}

Keywords: degradation of buildings; degree of technical condition; abandonment of renovation works; maintenance management of building; use management of building; assessment of the technical condition of the building

\section{Introduction}

Proper maintenance of the building depends on maintaining its technical condition at an appropriate level [1-4]. This can be obtained by carrying out renovation works on an ongoing basis [5-8]. However, renovation works are often not realized. Renovation is not carried out by the lack of the owner, improper manager or irresponsible users [9-12]. It is often difficult to get the residents' consent to renovate the building [12-14].

It is often difficult to obtain the residents' consent to renovate the building. In Norway, research has been conducted on factors influencing residents' belief in sustainable energy-efficient renovation. The results of the research are presented in the article [15]. In Sweden, an analysis of factors influencing the spending of investment funds for renovation purposes related to the improvement of energy efficiency was also carried out [16]. The awareness of housing security is one of the most important aspects of housing security management. Therefore, in order to examine the residents' awareness, surveys were carried out using consultation questionnaires and statistical software. The results of the research presented in the paper [17] show that in Shanghai residents do not understand the law on housing management, policy and security awareness. Studies have also been conducted on the social risks associated with apartment demolition from a stakeholder perspective [18]. Risks related to stakeholders and their interrelationships have been investigated on the basis of interviews. Guides for building owners and authorities have been developed, e.g. [19], to help ensure the safety of our ageing building infrastructure. Ensuring the proper technical condition is one of the most important problems during the operation of each technical facility [e.g. 20-28].

Negligence in renovation works often applies to historic buildings. Objects listed in the register of monuments are subject to strict conservation protection. Unfortunately, due to the higher costs of 
renovation and the need to apply supervision during the work in the historic buildings, many valuable buildings are damaged. What will be completely destructed as a result of negligence, omissions and atmospheric factors can only be reconstructed to resemble historical elements in its form and material, but it will be only a reproduction, not an original element, which is a tangible work of previous generations. Therefore, regular repairs, renovations and ongoing maintenance are extremely important in order to prevent the complete destruction of the objects and thus the loss of their historic value. The public awareness is of great importance here, so that in the pursuit of innovation and individuality, we do not forget about the monuments, which are the testimony of a bygone era, showing the craftsmen's craftsmanship, skills and level of knowledge of those times. We must remember that historic buildings are an indispensable element of spatial development and constitute our common national good [29-32].

Research is needed to identify the most urgent renovations needed. It is very problematic for managers to make decisions about the type, scope and date of renovation of buildings.

The aim of the article is to present the developed method of planning renovation works based on the consequences of lack of renovation works. The planned surveys will contribute to the identification of the needs for the implementation of renovation investments, which allows to search for methods of effective prevention of building degradation and implementation of preventive measures.

The methods of planning renovation work are the subject of many studies. The basic criterion in planning renovation works is most often the positive consequences of a certain scope of renovation works [4, 33-38]. The authors have undertaken research with a different perspective. The main assumption of the new method is the analysis of consequences of lack of renovation works. The worse the consequences of not carrying out renovation works on a given element in a building, the more necessary the renovation should be.

\section{Materials and Methods}

The proposed method consists in identifying the most urgent repairs needed. The method MUBAR (maintenance Management in an Un-renovated Building with Abandoning Renovation) is based on the premise that the higher the consequence of lack of renovation works, the more important the renovation is.

For this purpose, the consequences of lack of renovation works were determined, as well as the measures and weights of these consequences.

The building was divided into components. For each component, the consequences of abandoning renovation work on that component were determined. Criteria for the consequences of abandoning renovation works have been defined:

$\mathrm{C} 1$ - building degradation,

$\mathrm{C} 2$ - building structure damage,

C3 - lack of user safety,

C4 -negative impact on the environment,

C5 - lack of comfort in use,

C6 - effect on damage of other elements,

C7 - lack of aesthetics.

Then for each criterion the weighting was determined by the AHP method [39].

Each element of the building has been inspected for its technical condition, as a result of which the percentage of its technical wear has been determined. Thanks to the dependence of the degree of technical wear of the element on the aspect of consistency coefficient, it is possible to obtain the renovation coefficient for each building element. Indicators ranked from the largest to the lowest size will determine the urgency of renovation of elements in the building. 
By using the solution of equation (1) we obtain the values assigned to each investigated element in a concrete building. The numerical values, which are the result of the study, are the indicators of the order in which the repairs are performed $\mathrm{Mi}, \mathrm{j}$. The higher the indicator is, the more necessary is the renovation of the i-th element in j-th object. However, the indicator does not mean any physical size of the renovated elements, it is only used to rank the building's elements due to the proposed order of performing the renovations.

$$
\mathrm{M}_{\mathrm{i}, \mathrm{j}}=E_{i, j} S z_{i, j}
$$

where:

- Ei,j-coefficient of the consequences of abandonment of renovation works;

- Szi,j- degree of technical condition;

- $\quad \mathrm{i}$-denotes an ordinal number of an element in a building, $i=1,2,3, \ldots, n$;

- $j$-denotes consequences, $j=1,2, \ldots, 7$.

The coefficient Ei,j of the consequences of abandonment of renovation works defined as the sum of the weights for each element:

$$
\mathrm{E}_{\mathrm{i}, \mathrm{j}}=\sum_{i=1}^{n} C_{j}
$$

where:

- $\quad \mathrm{Ei}, \mathrm{j}$-coefficient of the consequences of abandonment of renovation works;

- $\quad \mathrm{j}$-weight of consequences j;

- $\quad \mathrm{i}$-denotes an ordinal number of an element in a building, $i=1,2,3, \ldots, n$;

- $j$-denotes consequences, $j=1,2, \ldots, 7$.

\begin{tabular}{|c|c|c|c|c|c|c|c|c|}
\hline \multirow[b]{2}{*}{$\begin{array}{l}\text { Damaged } \\
\text { component }\end{array}$} & \multicolumn{7}{|c|}{ consequences } & \multirow[b]{2}{*}{ 压 } \\
\hline & 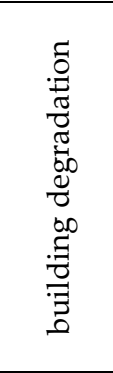 & 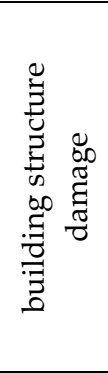 & 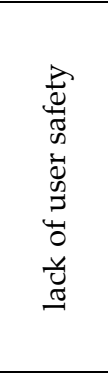 & 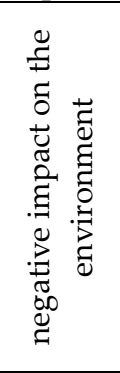 & 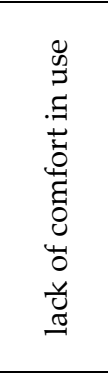 & 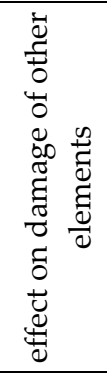 & 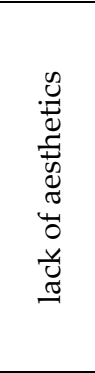 & \\
\hline Brick foundations & 35.000 & 26.333 & 21.533 & 10.486 & 11.933 & 12.733 & 0.000 & 118.019 \\
\hline Masonry brick walls & 35.000 & 26.333 & 21.533 & 10.486 & 11.933 & 12.733 & 2.073 & 120.092 \\
\hline Masonry partition walls & 35.000 & 26.333 & 21.533 & 10.486 & 11.933 & 12.733 & 2.073 & 120.092 \\
\hline Wooden beam ceilings & 0.000 & 26.333 & 21.533 & 10.486 & 11.933 & 12.733 & 2.073 & 85.092 \\
\hline Wooden stairs & 0.000 & 0.000 & 21.533 & 0.000 & 11.933 & 12.733 & 2.073 & 48.273 \\
\hline Roof rafter & 0.000 & 26.333 & 21.533 & 0.000 & 11.933 & 12.733 & 2.073 & 74.606 \\
\hline Tail caver & 0.000 & 26.333 & 21.533 & 0.000 & 11.933 & 12.733 & 2.073 & 74.606 \\
\hline Gutters and drainpipes & 0.000 & 26.333 & 0.000 & 0.000 & 0.000 & 12.733 & 2.073 & 41.140 \\
\hline Internal plasters & 0.000 & 0.000 & 0.000 & 0.000 & 0.000 & 12.733 & 2.073 & 14.806 \\
\hline External plasters & 0.000 & 0.000 & 0.000 & 0.000 & 0.000 & 12.733 & 2.073 & 14.806 \\
\hline Windows & 0.000 & 0.000 & 0.000 & 0.000 & 11.933 & 12.733 & 2.073 & 26.740 \\
\hline Doors & 0.000 & 0.000 & 0.000 & 0.000 & 11.933 & 12.733 & 2.073 & 26.740 \\
\hline Glazing & 0.000 & 0.000 & 0.000 & 0.000 & 11.933 & 12.733 & 2.073 & 26.740 \\
\hline Wooden floor & 0.000 & 0.000 & 0.000 & 0.000 & 11.933 & 0.000 & 2.073 & 14.006 \\
\hline
\end{tabular}

Table 1. The consequences of abandoning renovation works. 


\begin{tabular}{|c|c|c|c|c|c|c|c|c|}
\hline Wall coatings & 0.000 & 0.000 & 0.000 & 0.000 & 0.000 & 0.000 & 2.073 & 2.073 \\
\hline Woodwork oil coatings & 0.000 & 0.000 & 0.000 & 0.000 & 0.000 & 12.733 & 2.073 & 14.806 \\
\hline Cores of ceramic cookers & 0.000 & 0.000 & 0.000 & 10.486 & 11.933 & 12.733 & 2.073 & 37.225 \\
\hline Tiled stove & 0.000 & 0.000 & 0.000 & 10.486 & 11.933 & 12.733 & 2.073 & 37.225 \\
\hline Central heating pipes & 0.000 & 0.000 & 21.533 & 0.000 & 11.933 & 12.733 & 2.073 & 48.273 \\
\hline Boilers and heaters for c.h. & 0.000 & 0.000 & 21.533 & 0.000 & 11.933 & 12.733 & 2.073 & 48.273 \\
\hline Water supply and sewage pipes & 0.000 & 0.000 & 0.000 & 10.486 & 11.933 & 12.733 & 2.073 & 37.225 \\
\hline Water supply and sanitation fittings & 0.000 & 0.000 & 0.000 & 10.486 & 11.933 & 12.733 & 2.073 & 37.225 \\
\hline Gas pipes & 0.000 & 0.000 & 21.533 & 10.486 & 11.933 & 12.733 & 2.073 & 58.759 \\
\hline Electrical installations & 0.000 & 0.000 & 21.533 & 10.486 & 11.933 & 12.733 & 2.073 & 58.759 \\
\hline
\end{tabular}

The obtained results, which are indicators of the order in which renovation works should be performed for particular elements of all tested buildings, after being ranked from the highest to the lowest value, indicate the order in which all building components should be renovated.

\section{Case study: a neo gothic palace}

The palace and grange complex is located in the western part of the village. The entranceway leads from the south side onto a vast yard, around which outbuildings are located. The palace, situated with the facade facing the west, is located in the eastern part of the yard. Behind the palace, in the eastern and southern part, is a landscape park. The body of the building was created by various extensions added to the main body of the building.

The earliest mention of the village of Drwalewice (Driwalowitz 1295 r., Wallwitz $1791 \mathrm{r}$.) dates back to the $13^{\text {th }}$ century, as an emolument of the parish in Solniki [40-41]. From the middle of the $14^{\text {th }}$ century, the village belonged to the von Unruh family. The building of the renaissance residence - a fortified manor, is connected with Hans Wolf von Unruh. The village changed owners a number of times. Near the end of the EVIII century, the estate was bought by P.G. Strempel, who rebuilt the manor house. Since 1872, the owners of Drwalewice were the von Eichmann family, and, in 1875, another reconstruction of the building took place [40-41].

The palace, erected from stone and brick, is plastered, two-story with a finished attic and basement, and covered by a flat roof hidden behind crenellation. The majority of the basements are covered by a brick cross-barrel vault; the rooms in the south-west corner are made as a segmented ceramic vault on steel beams. Over the ground floor and first floor, there is a wood ceiling with sound boarding, with only a room on the ground floor, situated in the eastern central part or the building, being covered by a groin vault. In an upstairs room, located in the south part of the building, the moldings have been partially maintained. The ceiling covering the stairwell is decorated with a rosette. In the hall on the ground floor and first floor, there are arcades supported by four columns and eight half-columns covered by a wooden ceiling. The window openings are covered with dripstones - rectangular on the lower floor, and narrow, and ogee-arched on the upper one. A decorative element of the facade is a portal with a balcony, with supports in the shape of griffins. The balustrade is ceramic openwork, with an oak leaf motif. Above the balcony, a cartouche is laid in masonry.

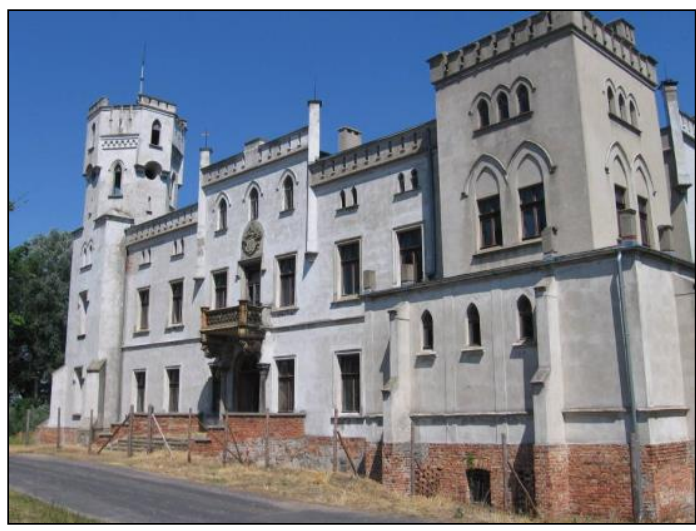


Figure 1. Front elevation. View from the south-western side. Body of the building - irregular rectangle enriched with additions: towers in the corners, a balcony on the front elevation, terraces on the side elevations, roof - multi-hipped flat roof hidden behind the attic in the form of a crenellation

The current form of the palace was shaped as a result of three building phases. In the basements, the relicts of a renaissance manor have been maintained. From the reconstruction in 1791 are the rooms of the main body. The towers in the corners, terraces in side elevations and a balcony in the front elevation were added on in the ${ }^{19 t h}$ century. The building was originally founded on a square plan, in the second phase extended to a rectangle, and in the third - enriched with numerous extensions.

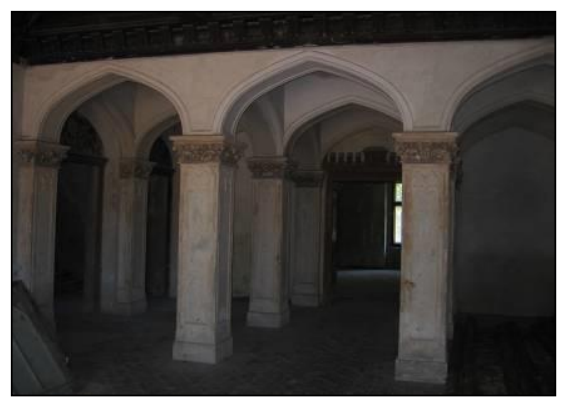

Fig. 2. Ground floor. View onto the arcades in the central part. Preserved decorative caps. Plasters of columns original, arcades - secondary

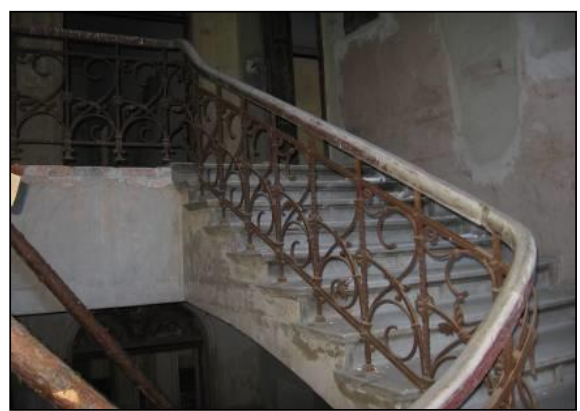

Fig. 3. Stairwell fragment. Preserved castiron balustrade with floral ornamentation

Before the building was profoundly rebuilt into a Neo - Gothic palace, it had been subjected to earlier modernization in 1791. The function of the building changed - from defensive to residential. The reconstruction in the $1^{\text {th }}$ century was not limited to introducing new Neo Gothic décor; it also covered enriching the bodies of the building with numerous annexes. The main body of the palace was coped with an attic crenellation. The tri-axial center of the façade and remaining elevations was raised and surounded with pinnacles. The ogival main entrance was accented by a balcony placed above it, with a ceramic balustrade and griffins. The body of the building was decorated with annexes. On the north side, a tower was added on - four-sided in the lower part, with the upper transitioning into an octagon. A loggia was added on to the tower on the north side. The east (garden) elevation was enriched by a protrusion with a balcony, the south elevation - by two annexes lower than the body of the palace. The inside also received a new Neo Gothic decor. The hall was divided into a front part covered by a wooden ceiling as well as a two-bay vaulted cloister supported by square columns and pilasters with decorative caps located further in. In the tower, in the south part of the building, in the basement and on the ground floor, a colonnade running along the southern and western walls is found. The arcades are supported by slender iron columns with caps covered by stylized floral ornamentation. The doors are decorated by a motive of ogival recesses, a stylized rosette and crenellated lintels. The staircase leading to the upstairs is decorated by a forged balustrade.

The assessment of the technical condition of individual building components was prepared on the basis of carried out inspections, periodic uncovers and test measurements [42]. 


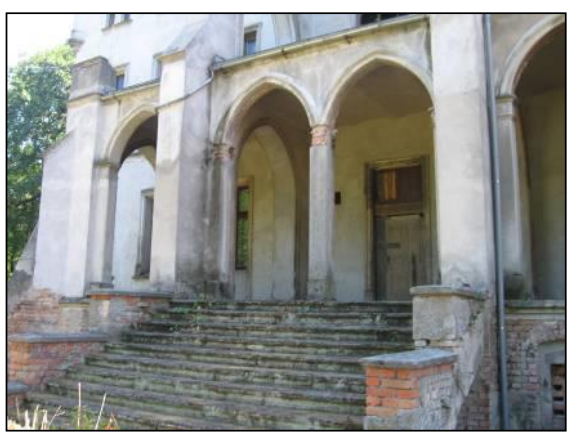

Fig. 4. Fragment of the northern elevation. Numerous damp stains on the terrace, destroyed steps, missing areas of plaster. Destroyed column caps.

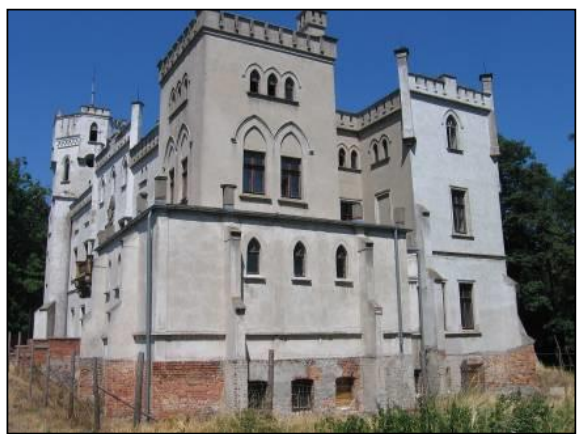

Fig. 5. Southern elevation. View from the south-western side. Walls covered by a cement-lime plaster applied in the 80 s of the $20^{\text {th }}$ century. Lack of balustrade on the tower terrace. Lack of plaster on the foundation plinth

The foundation of the building are strip foundations of various dimensions with an offset of 15 $\mathrm{cm}$, made from boulders on lime mortar with an addition of clay; the average diameter of the boulders is approx. $60-70 \mathrm{~cm}$. The depth of the strip foundation is approximately $80-120 \mathrm{~cm}$ below the level of the basement floors. Uncovers of the foundations in the north-eastern and south-western part of the building were carried out. Severe damp of surfaces from the groundwater was determined. The soil in areas of the foundation uncovers is loamy sand. The level of groundwater is above the level of the foundation. There is a lack of vertical and horizontal damp insulation.

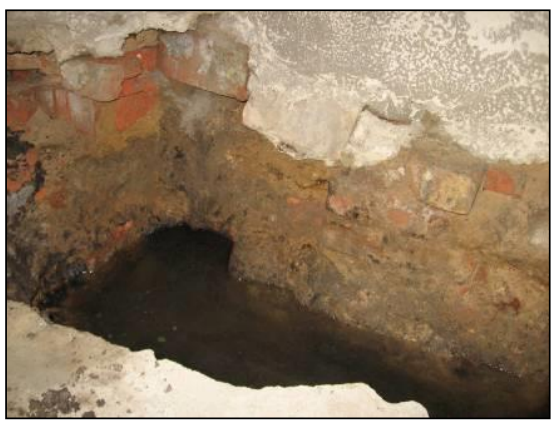

Fig. 6. Basement in the middle part of the building, fragment. Foundation uncover. High level of groundwater, severely damp wall

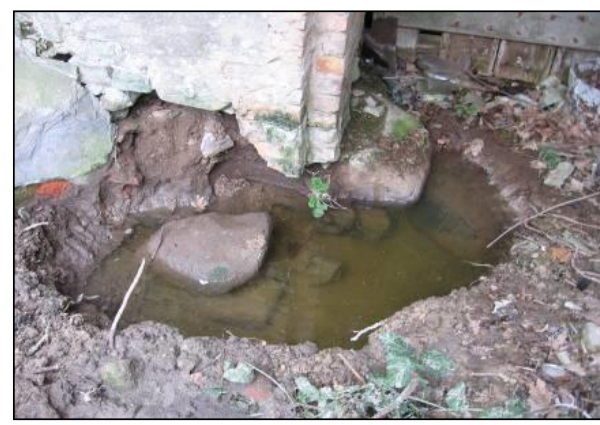

Fig. 7. Wall of northern elevation, fragment. Foundation uncover. Foundation from boulders. Visible groundwater table

The walls of the basement were made from boulders and class 7.5 - 10 fired, solid brick, on cement-lime mortar (composition of mortar lime:cement:sand =3:1:5), and plastered on both sides. The thickness of the walls ranges from $65 \mathrm{~cm}$ to $210 \mathrm{~cm}$. The middle, oldest part, is on laid in lime mortar with an addition of clay. The outside walls of the ground floor (thickness ranging from 70 to $82 \mathrm{~cm}$ ), first floor (thickness from 42 to $82 \mathrm{~cm}$ ) and attic (thickness from $20 \mathrm{~cm}$ to $54 \mathrm{~cm}$ ) are made from fired, class $7.5-10$, solid brick on lime-cement mortar (composition of mortar lime:cement:sand $=3: 1: 5)$, and are plastered on both sides.

Slight cracks and scratches, $1-2 \mathrm{~mm}$ in width, are present, e.g. a crack on the western wall running between the window openings at the level of the ceiling above the ground floor. The cracks are caused by external factors (moisture, temperature, etc.). Cracks are the results of slight shifts over a period of many decades. Such shifts do not currently occur.

The walls of the basements are severely damp. From the outside, large amounts of efflorescence, including salt efflorescence, and discolorations are visible from the inside on the plasters. In the east part of the building, on the ground floor, the walls are severely damp due to water entering from the ground by capillary rise. The walls of the room under the terraces are damp from rainwater.

Inside walls of the ground floor and first floor (ranging in thickness from 12 to $78 \mathrm{~cm}$ ), are made from class 7.5 - 10 fired, solid brick laid in lime-cement mortar (composition of mortar lime: cement: 
sand = 3:1:5), and plastered on both sides. Some of the inside walls of the attic are studwork walls (12 $\mathrm{cm}$ thickness) made from pine posts and beams covered by boards and reed.

Cracking is not present on the inside masonry walls. The walls do not require repairs and protection. Only on a wall in the room covered by a groin vault, on the wall from the direction of the hall, is a vertical structural crack visible.

Wooden elements in the studwork walls are heavily dampened, with the walls needing to be replaced by new ones. The majority of the basements are covered by a brick barrel vault (group 1 of brick). Two rooms in the south-west corner were made as ceramic segmental vaults on I 2000 steel beams, with $1.5 \mathrm{~m}$ spread. Over the ground floor and the first floor, there is a wooden ceiling with sound boarding. The ceiling beams measure $18 \times 23 \mathrm{~cm}$ or $20 \times 25 \mathrm{~cm}$, with $80-100 \mathrm{~cm}$ spread.

The room of the hall on the ground flood is covered by a decorative wooden ceiling made from profiled beams and coffers. The room of the ground floor, situated in the eastern, middle part, is covered by a vault made from brick on lime mortar (group 1 of brick). In the room in the northeastern part of the building, there is a ceiling on I 200 steel beams, on the underneath finished by fake beams (profiles from boards), creating a coffered ceiling. .

In a room upstairs, in the south part of the building, partially preserved moldings are found. The ceiling covering the stairwell is decorated with a rosette.

In the upstairs rooms, in the north-western part of the building, there is a ceiling made of prefabricated concrete ceiling slabs from I 200, with a spread of 1.2. $\mathrm{m}$.

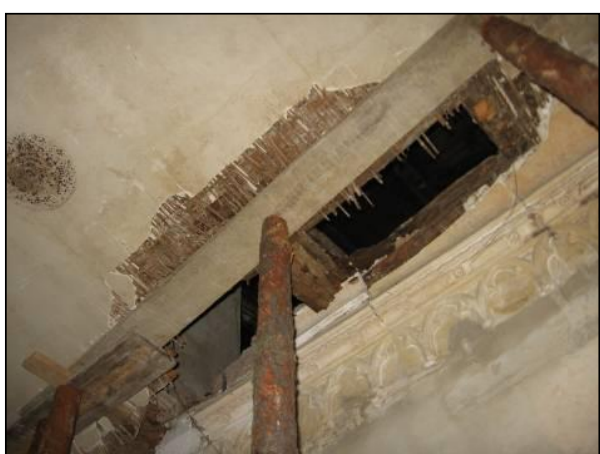

Fig. 8. Upstairs, fragment of ceiling above the room in the eastern part. Bad condition of the ceiling. Ceiling temporarily shored

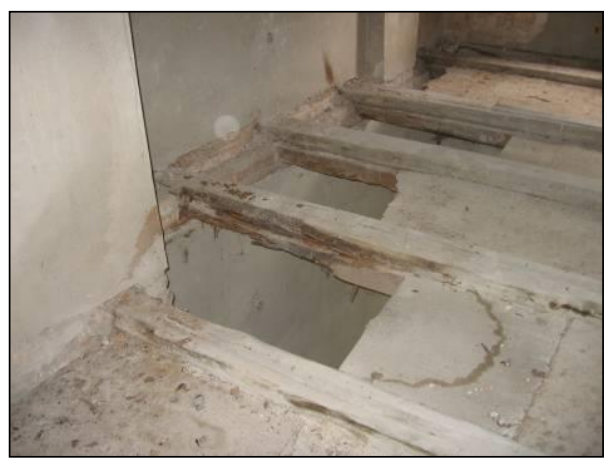

Fig. 9. Attic, fragment of the floor in the central part. Corroded ends of floor beams. Lack of flooring and ceiling

In the room upstairs, in the northern part of the building, the floor slab deflection is approximately $15 \mathrm{~cm}$. The floor requires additional support. Upstairs, the ceiling beams are significantly damp. The wooden construction of the ceilings requires general repairs, partial strengthening and the partial replacement of elements. Additionally, it is recommended that the wood be impregnated with insecticides and fungicides.

In the hall on the ground floor and upstairs, there are arcades supported by four columns and eight half columns covered by a wooden ceiling. In the tower in the south side of the building, in the basement and on the ground floor, a colonnade running along the south and west walls can be found. The arcades are supported by slim iron columns with column heads covered by stylized floral ornamentation.

Cracking is present in the arcades in the hall: a vertical crack running along the arch of the arcades on the ground floor and first floor (located on the south side), $5 \mathrm{~mm}$ wide, as well as horizontal cracks, $2 \mathrm{~mm}$ in width, between the central wall and the arcade covering. Arcades in the south tower are heavily damp due to the leaking terrace.

The construction of inside stairs in the northern part of the building is brick arched, supported by a steel beam, with wooden treads and risers. The cast-iron balustrade contains a floral motive. Stairs in the south side of the building - reinforced concrete, were built in the 80s of the 20th century. The outside stairs are concrete. 
The construction of the roof framework is of the rafter-purlin type from pine, comprising a few parts: central, pitched, with the roof ridge perpendicular to the front elevation, and two pitched side parts; the layout of the roof ridges is parallel to the front elevation as well as rafter frameworks over the towers. The roof is covered with roofing felt, with the end walls coped with an attic imitating a crenellation.

Technical condition of roof framework - varied. Bending and severe dampening of elements occurs locally. Thermal insulation is of 5-10 cm thick Styrofoam. The Styrofoam underwent oxidation. The roof covering of roofing felt on tar is in bad condition and the boards need to be replaced. The chimneys are in good condition.

The gutters, downpipes, and flashing are of galvanized steel. Missing parts of the gutters and downpipes allow rainwater to penetrate inside, leading to the destruction of outside platers and the dampening of the walls. .

The floor in the rooms of the basements is concrete. On the ground floor and first floor, there are wooden or concrete floors, missing in some of the rooms. In the hall on the ground floor - there is terracotta flooring, $17 \times 17 \mathrm{~cm}$. There is no flooring in the attic. The floors in the basement are damp and cracked. Concrete flooring in the basements requires repairs and patching.

On the ground floor, first floor and attic, the windows are double-paned, casement, folding with a fanlight, with wooden frames and wooden windowsills. In the basements, the wooden windows are single-pane loom windows. The window openings closed with weather molding on the lower floors are rectangular, on the upper floors - narrow, ogival. The window frames are from the $80 \mathrm{~s}$ of the $20^{\text {th }}$ century. The doors on the ground floor are two-winged; the ones on the first floor and in the attic did not retain. The front opening is of an ogival profile. On the entrance to the balcony are double-winged glazed box doors. Some of the doors on the ground floors are original, from the reconstruction that took place in the $19^{\text {th }}$ century. The preserved doors and door frames are partially infested with wood-destroying pests and mechanical damage is visible. The doors require repairs and conservation.

The original plasters were stripped. Currently, the walls are covered by a cement-lime mortar with a thickness of approximately $2 \mathrm{~cm}$, laid in the $80 \mathrm{~s}$ of the $20^{\text {th }}$ century.

A decorative element on the front elevation (west) is the balcony on supports in the shape of griffins with an openwork balustrade with an oak leaf motif. The structure of the balcony is a flat light masonry slab on steel beams. Architectural details are ceramic. An arms cartouche can be found over the balcony.

Window openings are closed with dripstones. At the level of the ceiling over the ground floor, the elevation is decorated with an inter-story cornice. The windows of the tower are enriched with a kinked profile that is adjacent to the higher part of the frame of the window opening.

In rooms at the level of the basements and ground floor, the walls are covered with a limecement and cement-lime mortar (applied in the $80 \mathrm{~s}$ of the $20^{\text {th }}$ century), $1.5 \mathrm{~cm}$ in thickness. Original cement plaster and polychromes are present on the walls of the stairwell. In wet rooms, the walls are partially covered with ceramic tiles. Damp, numerous cracks and missing plaster all occur in the rooms of the basements.

The inside walls are not painted. On the walls of the stairwell and arcade columns in the central part of the building are the remains of Neo Gothic polychromes.

The building contains the remains of a water and sewage service system as well as a very inadequate heating system. The wiring system is damaged, with makeshift connections to the light sources posing a fire hazard.

The results of the carried out assessment of the technical conditions [42] indicates that there is a need for a complete renovation of the building. 
Table 2. The results of the assessment of the technical conditions

\begin{tabular}{|c|c|}
\hline Damaged component & $\mathrm{SZi}[\%]$ \\
\hline Foundations & 60 \\
\hline Masonry brick walls & 40 \\
\hline Masonry partition walls & 80 \\
\hline Wooden beam ceilings & 70 \\
\hline Wooden stairs & 20 \\
\hline Roof rafter & 60 \\
\hline Tail caver & 40 \\
\hline Gutters and drainpipes & 80 \\
\hline Internal plasters & 30 \\
\hline External plasters & 30 \\
\hline Windows & 20 \\
\hline Doors & 70 \\
\hline Glazing & 10 \\
\hline Wooden floor & 100 \\
\hline Wall coatings & 100 \\
\hline Woodwork oil coatings & 80 \\
\hline Cores of ceramic cookers & 80 \\
\hline Tiled stove & 100 \\
\hline Central heating pipes & 100 \\
\hline Boilers and heaters for c.h. & 100 \\
\hline Water supply and sewage pipes & 100 \\
\hline Water supply and sanitation fittings & 100 \\
\hline Gas pipes & 100 \\
\hline Electrical installations & 100 \\
\hline
\end{tabular}

The wooden ceilings over the ground floor and first floor do not fulfill the specified ultimate limit states of load-bearing capacity, and the immediate renovation of the ceilings in a manner that allows for preserving as much of the historic substance as possible in an unchanged form is recommended.

Missing pieces of ceiling decorations of the decorative coffered ceiling in the entrance hall as well as in the north-east room on the ground floor ought to be completed and impregnation with wood preservative agents carried. Renovation of the moldings, polychromes and staircase balustrades inside the building is recommended. The moldings in the room in the south-east corner are in good condition - do not require repairs, whereas moldings over the room of the stairwell are in a bad state; ceiling beams and the ceiling need to be replaced. The moldings are prefabricated plaster elements (made according to an architectural template and installed on spot). They ought to be taken down, and put back up after having constructed a new ceiling. Photographic documentation should be carried out prior to commencing the works. The taken down wood paneling should be subjected to conservation works, filling in the missing elements, and put back up in its original place.

The bad technical condition of the roof structure indicates the necessity of immediate repairs of the framework. A new roof cover and thermal insulation of the roof ought to be carried out, replacing all flashing, gutters and downpipes. The foundation needs to be dried, equipping the building with drainage. 
In the arcades in the halls, vertical and horizontal cracking occurs: a structural crack running vertically on the arcade parallel to the east wall as well as horizontal crack between the arcade covering and the southern wall. In an effort to establish the reason behind the existing cracks and scratches, non-destructive tests were carried out. The monitoring of the cracking allowed for assessing the stabilization of the cracks. Control strips were placed on the arcades. The observation of the strips did not reveal shirting. The cracks therefore originate from an earlier period and are currently not expanding - are stabilized.

From the analysis of the building structure, it was determined that the reason behind cracking is the shifting between the hall and the room covered by the vault. A change in the geometry of the wall is connected with excessive bending of the ceiling and over-loading of the pillars on the vault. The emerging cracks of the arcades do not threaten the safety of the structure.

Vertical structural cracks running through the third, fifth and seventh axis were observed on the west outside wall. Here too, control strips were placed to determine the dynamics of the cracking. Observation of the strips did not reveal shifting; the cracking therefore originates from an earlier period and is currently not expanding - is stabilized. The structural walls of the building do not reveal deformations and damage that could threaten the structural safety or the safety of use, disqualifying the building from further service functions.

Renovation of the inside and outside stairs ought to be carried out, and floors and flooring replaced with new ones with the exception of the flooring in the entrance hall; outside plasters need to be repaired, filling in the missing areas. There is a need to install heating, water and sewage, electrical and lighting protection systems.

The windows should be replaced with new ones, with their designs similar to the original ones. The doors (doors and doorframes) should be subjected to renovation and conservation. Missing doors ought be made according to designs reflecting those of the original doors.

The structure of the balcony slab over the main entrance ought to be reinforced and completed, with the preservation of details, and cleaned. Sandstone and ceramic elements present in the front elevation, i.e.: arms cartouche, balcony balustrade, stairs, porch column caps, griffins supporting the balcony slab and terrace balustrade in the southern elevation, should all be subjected to conservation and renovation. Details ought to be recreated based on the remaining elements. Insulation of the terraces needs to be carried out, the original balustrades restored and missing areas patched up, with the entirety of the balcony subjected to conservation. On the elevations, missing parts of the molding and outside plasters should be patched up.

In the analysis all elements of the palace building in Drwalewice were taken into account. The obtained results are presented in Table 3 .

Table 3. Maintenance Management in the palace in Drwalewice

\begin{tabular}{cccc}
\hline Damaged component & $\mathbf{E}_{\mathbf{i}}$ & $\mathbf{S Z}_{\mathbf{i}}$ & $\mathbf{M}_{\mathbf{i}}$ \\
\hline Masonry partition walls & 120.092 & 80 & 9607.4 \\
Foundations & 118.019 & 60 & 7081.1 \\
Gas pipes & 58.759 & 100 & 5875.9 \\
Electrical installations & 58.759 & 100 & 5875.9 \\
Wooden beam ceilings & 85.092 & 70 & 5105.5 \\
Central heating pipes & 48.273 & 100 & 4827.3 \\
Boilers and heaters for c.h. & 48.273 & 100 & 4827.3 \\
Masonry brick walls & 120.092 & 40 & 4803.7 \\
Roof rafter & 74.606 & 60 & 4476.4 \\
Tiled stove & 37.225 & 100 & 3722.5 \\
Water supply and sewage pipes & 37.225 & 100 & 3722.5
\end{tabular}




\begin{tabular}{cccl} 
Water supply and sanitation fittings & 37.225 & 100 & 3722.5 \\
Gutters and drainpipes & 41.14 & 80 & 3291.2 \\
Tail caver & 74.606 & 40 & 2984.2 \\
Cores of ceramic cookers & 37.225 & 80 & 2978 \\
Doors & 26.74 & 70 & 1871.8 \\
Wooden floor & 14.006 & 100 & 1400.6 \\
Woodwork oil coatings & 14.806 & 80 & 1184.5 \\
Wooden stairs & 48.273 & 20 & 965.5 \\
Windows & 26.74 & 20 & 534.8 \\
Internal plasters & 14.806 & 30 & 444.2 \\
External plasters & 14.806 & 30 & 444.2 \\
Glazing & 26.74 & 10 & 267.4 \\
Wall coatings & 2.073 & 100 & 207.3 \\
\hline
\end{tabular}

In Table 3, the building components have been ranked in value of Mi factor from the highest to the lowest. The obtained order is an indicator of the urgency of renovation works. Based on the results obtained, it can be concluded that the value of technical wear and tear is not the same as the necessity of carrying out repair works.

\section{Conclusions}

The proposed method is a new approach to determining the urgency of renovation works. Always in planning methods, the effect of renovation works is taken into account, and in the MUBAR method, differently, the effect of failure to complete renovation works.

The palace in Drwalewice is not in use as of today. Besides the natural wear of materials and the destructive influence of atmospheric and biological factors, the bad technical condition is the result of the object not being in use. The lack of carried out repairs caused the progressing deterioration of the building to accelerate. Planned renovation works will stop this process. In the area of Middle Odra, there are over a hundred manors and palaces that remain. The majority of them, however, are not in use, with their technical conditions undergoing continuous deterioration. The presented palace in Drwalewice is among such. Adaptions to current service needs, as will be the case in the Drwalewice palace, will allow for these buildings to be saved from further destruction.

Author Contributions: Conceptualization, BN.; methodology, BN.; validation, BN.; formal analysis, BN.; investigation, $\mathrm{BN}$.; resources, $\mathrm{BN}, \mathrm{MM}$; data curation, BN.; writing-original draft preparation, $\mathrm{MM}, \mathrm{BN}$.; writing-review and editing, MM., BN.

Funding: This research received no external funding.

Conflicts of Interest: The authors declare no conflict of interest.

\section{References}

1. Morelli, M.; Lacasse, M.A. A systematic methodology for design of retrofit actions with longevity. J. Build. Phys. 2019, 42, 585-604.

2. Alshubbak, A.; Pellicer, E.; Catala, J.; Teixeira, J. A Model for identifying owner's needs in the building life cycle. J. Civ. Eng. Manag. 2015, 21, 1046-1060. 
3. Daniotti, B.; Lupica Spagnolo, S. Service Life Prediction Tools for Buildings' Design and Management. In Proceedings of the 11DBMC International Conference on Durability of Building Materials and Components, Istanbul, Turkey, 11-14 May 2008; doi:10.13140/RG.2.1.4311.6002.

4. Lounis, Z.; Vanier, D.J.; Lacasse, M.A.; Kyle, B.R. Decision-Support System for Service Life Asset Management: The BELCAM Project. Durability of Building Materials and Components; National Research Council Canada: Ottwa, ON, Canada, 1999, 4, 2338-2347.

5. Shen, Q.; Spedding, A. Priority setting in planned maintenance-Practical issues in using the multiattribute approach. Build. Res. Inf. 1998, 26, 169-180, doi:10.1080/096132198369940.

6. Vanier, D.; Tesfamariam, S.; Sadiq, R.; Lounis, Z. Decision models to prioritize maintenance and renewal alternatives. In Proceedings of the Joint International Conference on Computing and Decision Making in Civil and Building Engineering, Montréal, QC, Canada, 14-16 June 2006; pp. 2594-2603.

7. Bucoń, R.; Sobotka, A. Decision-making model for choosing residential building repair variants. J. Civ. Eng. Manag. 2015, 21, 893-901, doi: 10.3846/13923730.2014.895411.

8. Sherwin, D. A review of overall models for maintenance management. J. Qual. Maint. Eng. 2000, 6, $138-164$.

9. Jones, K.; Sharp, M. A new performance-based process model for built asset maintenance. Facilities 2007, 25, 525-535. doi:10.1108/02632770710822616.

10. Farahani, A.; Wallbaum, H.; Olof Dalenbäck, J. Optimized maintenance and renovation scheduling in multifamily buildings - A systematic approach based on condition state and life cycle cost of building components. Constr. Manag. Econ. 2019, 37, 139-155.

11. Biolek, V.; Hanák, T. LCC Estimation Model: A Construction Material Perspective. Build. 2019, 9, 182.

12. Bento Pereira, N.; Calejo Rodrigues, R.; Fernandes Rocha, P. Post-Occupancy Evaluation Data Support for Planning and Management of Building Maintenance Plans. Buildings 2016, 6, 45.

13. Daniotti, B.; Pavan, A.; Lupica Spagnolo, S.; Caffi, V.; Pasini, D.; Mirarchi, C. Benefits and Challenges Using BIM for Operation and Maintenance. In BIM-Based Collaborative Building Process Management; Springer Tracts in Civil Engineering; Springer: Berlin/Heidelberg, Germany, 2020; pp. 103-142.

14. Nowogońska, B.; Korentz, J. Value of Technical Wear and Costs of Restoring Performance Characteristics to Residential Buildings. Buildings 2020, 10, 9.

15. Madureira, S.; Flores-Colen, I.; de Brito, J.; Pereira, C. Maintenance planning of facades in current buildings. Constr. Build. Mater. 2017, 147, 790-802.

16. Hauge, Å.L., Thomsen, J. \& Löfström, E. How to get residents/owners in housing cooperatives to agree on sustainable renovation. Energy Efficiency 2013, vol. 6, pp. 315-328.

17. Nair G., Gustavsson L., Mahapatra K. Factors influencing energy efficiency investments in existing Swedish residential buildings. Energy Policy, 2010, vol. 38/6, pp. 2956-2963.

18. Ban J, Chen L. Evaluation of the factors influencing the housing safety awareness of residents in Shanghai. PLoS ONE 2010, vol. 15(1): e0227871.

19. Yu T, Shen GQ, Shi Q, Lai X, Li CZ, and Xu K. Managing social risks at the housing demolition stage of urban redevelopment projects: A stakeholder-oriented study using social network analysis. International Journal of Project Management. 2017, 35(6): 925-941.

20. Jeffrey L. Erdly, Thomas A. Schwartz, Building Facade Maintenance, Repair, and Inspection, ASTM International 2004.

21. Nowogońska, B. Diagnoses in the Aging Process of Residential Buildings Constructed Using Traditional Technology. Buildings 2019, 9, 126.

22. Fedorczak-Cisak, M.; Kowalska-Koczwara, A.; Nering, K.; Pachla, F.; Radziszewska-Zielina, E.; Śladowski, G.; Tatara, T.; Ziarko, B. Evaluation of the Criteria for Selecting Proposed Variants of Utility Functions in the Adaptation of Historic Regional Architecture. Sustainability 2019, 11, 1094.

23. Zavadskas, E.K.; Antucheviciene, J. Multiple criteria evaluation of rural building's regeneration alternatives. Build. Environ. 2007, 42, 436-451.

24. Fedorczak- Cisak, M.; Kotowicz, A.; Radziszewska-Zielina, E.; Sroka, B.; Tatara, T.; Barnaś, K. MultiCriteria Optimisation Of The Urban Layout Of An Experimental Complex Of Single-Family Nearly ZeroEnergy Buildings. Energies 2020, 13, 1541.

25. Sztubecka, M.; Skiba, M.; Mrówczyńska, M.; Bazan-Krzywoszańska, A. An Innovative Decision Support System to Improve the Energy Efficiency of Buildings in Urban Areas. Remote. Sens. 2020, 12, 259.

26. Leśniak, A.; Górka, M. Structural Analysis of Factors Influencing the Costs of Facade System Implementation. Appl. Sci. 2020, 10, 6021. 
27. Konior, J.; Sawicki, M.; Szóstak, M. Intensity of the Formation of Defects in Residential Buildings with Regards to Changes in Their Reliability. Appl. Sci. 2020, 10, 6651.

28. Leśniak, A.; Janowiec, F. Risk Assessment of Additional Works in Railway Construction Investments Using the Bayes Network. Sustainability 2019, 11, 5388.

29. Bottero, M.; D'Alpaos, C.; Oppio, A. Ranking of Adaptive Reuse Strategies for Abandoned Industrial Heritage in Vulnerable Contexts: A Multiple Criteria Decision Aiding Approach. Sustainability 2019, 11, 785.

30. Brebbia C. A. Structural Studies, Repairs and Maintenance of Heritage Architecture XII, 2011. WIT Press.

31. Bullen, P.A. Adaptive reuse of heritage buildings. Structural Survey 2011, Vol., 29 No. 5, pp. 411-421.

32. The Venice Charter: International Charter for the Conservation and Restoration of Monuments and Sites (1964), International Council on Monuments and Sites (ICOMOS), Second International Congress of Architects and Technicians of Historic Buildings, Venice 1964.

33. Branco, P.J.; Paiva, P.J. Assessment method of buildings' rehabilitation needs: Development and application. In Proceedings of the CIB World Congress, May 10-13, Salford UK, 2010.

34. Serrano-Jiménez, A.; Lima, M.L.; Molina-Huelva, M.; Barrios-Padura, Ángela Promoting urban regeneration and aging in place: APRAM - An interdisciplinary method to support decision-making in building renovation. Sustain. Cities Soc. 2019, 47, 101505.

35. Paulo, P.V.; Branco, F.; De Brito, J. BuildingsLife: a building management system. Struct. Infrastruct. Eng. 2013, 10, 388-397.

36. Serrat C., Gibert V. Survival Analysis Methodology for Service Live Prediction and Building Maintenance. XII DBMC International Conference on Durability of Building Materials and Components, Porto Portugal 2011.

37. Nowogońska, B. A Methodology for Determining the Rehabilitation Needs of Buildings. Appl. Sci. 2020, $10,3873$.

38. Shiue, F.-J.; Zheng, M.-C.; Lee, H.-Y.; Khitam, A.F.; Li, P.-Y.; Lee; Li Renovation Construction Process Scheduling for Long-Term Performance of Buildings: An Application Case of University Campus. Sustainability 2019, 11, 5542.

39. Nowogońska, B. Consequences of Abandoning Renovation: Case Study-Neglected Industrial Heritage Building. Sustainability 2020, 12, 6441.

40. Registration Card of Architecture and Building Monuments Palace in Drwalewice Archives of the Provincial Office for the Protection of Monuments in Zielona Góra, Zielona Góra, Poland. [in Polish].

41. Registration Card of Architecture and Building Monuments Palace complex in Drwalewicace Archives of the Provincial Office for the Protection of Monuments in Zielona Góra, Zielona Góra, Poland. [in Polish].

42. Nowogońska B., Eckert W. Technical expertise of the palace in Drwalewice. [in Polish]. 